
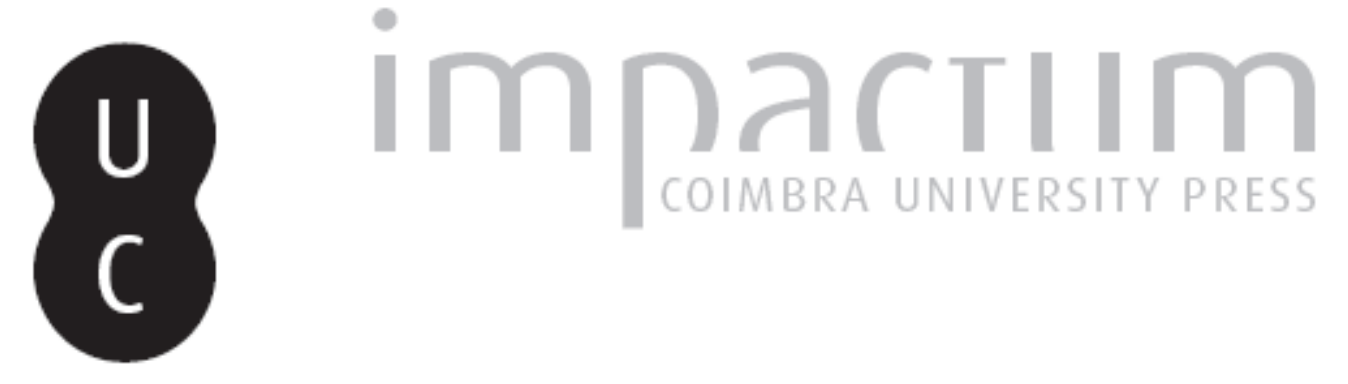

\title{
Multinational corporations, foreign investment, and royalties and license fees: effects on host-country total factor productivity
}

\author{
Autor(es): $\quad$ Pessoa, Argentino
}

Publicado por: Faculdade de Economia da Universidade de Coimbra

URL persistente:

URI:http://hdl.handle.net/10316.2/25245

DOI:

DOI:http://dx.doi.org/10.14195/2183-203X_28_1

Accessed : $\quad$ 26-Apr-2023 13:15:36

A navegação consulta e descarregamento dos títulos inseridos nas Bibliotecas Digitais UC Digitalis, UC Pombalina e UC Impactum, pressupõem a aceitação plena e sem reservas dos Termos e Condições de Uso destas Bibliotecas Digitais, disponíveis em https://digitalis.uc.pt/pt-pt/termos.

Conforme exposto nos referidos Termos e Condições de Uso, o descarregamento de títulos de acesso restrito requer uma licença válida de autorização devendo o utilizador aceder ao(s) documento(s) a partir de um endereço de IP da instituição detentora da supramencionada licença.

Ao utilizador é apenas permitido o descarregamento para uso pessoal, pelo que o emprego do(s) título(s) descarregado(s) para outro fim, designadamente comercial, carece de autorização do respetivo autor ou editor da obra.

Na medida em que todas as obras da UC Digitalis se encontram protegidas pelo Código do Direito de Autor e Direitos Conexos e demais legislação aplicável, toda a cópia, parcial ou total, deste documento, nos casos em que é legalmente admitida, deverá conter ou fazer-se acompanhar por este aviso.

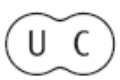




\section{N $\odot$ T $A E G \odot N O M I C A S$}

\section{ARGENTINO PESSOA MULTINATIONAL CORPORATIONS, FOREIGN INVESTMENT, AND ROYALTIES AND LICENSE FEES: EFFECTS ON HOST-COUNTRY TOTAL FACTOR PRODUCTIVITY}

ORLANDO GOMES TIME PREFERENCE AND CYCLICAL ENDOGENOUS GROWTH IN AN AK GROWTH MODEL

\section{$-3$}

$\rightarrow$

c.

6

3

$\theta$

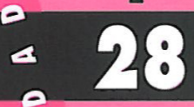

-

$\omega$

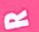

w

$\Rightarrow$

-

$z$

E

$a$

a

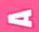

-

EF

$\odot$

$z$

$\odot$

v

w

w

a

w

0

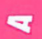

0

$\sim$

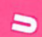

ن 

and License Fees: Effects on Host-Country Total Factor Productivity

Neste artigo examinamos, do ponto de vista teórico e empírico, a relação entre IDE (Investimento Directo Estrangeiro) recebido e PTF (produtividade total dos factores), à luz do paradigma OLI (organização, localização e internalização). Utilizamos técnicas de regressão em painel para analisar os efeitos do IDE recebido e do pagamento de royalties e Licenças sobre a PTF agregada duma amostra de 16 países da OCDE, entre 1985 e 2002. Os testes empíricos mostram que o IDE recebido e o pagamento de royalties e licenças tem um impacto positivo na PTF dos países e, também, sugerem que a dimensão dos efeitos positivos está dependente do nível de desenvolvimento desses países. Por outro lado, a nossa investigação mostra que, quando outros factores permanecem constantes, o IDE recebido e as royalties pagas são substitutos no impacto positivo que exercem sobre a PTF.
Cet article analyse, du point de vue théorique et empirique, la relation entre l'investissement direct étranger (IDE) reçu et la PGF (productivité globale des facteurs). Avec un encadrement théorique inspiré du paradigme OLI (organisation, localisation et internalisation), nous utilisons des techniques de régression sur un panel de donnés pour mesurer les impacts des entrées d'IDE et des redevances payées à l'étranger sur la PGF à partir d'un échantillon de 16 pays de I'OCDE, entre 1985-2002. Les tests empiriques démontrent que I'IDE entré et le paiement de redevances ont un impact positif sur la PGF. Ils montrent aussi que la dimension de l'effet positif dépend du niveau de développement de ces pays. Par ailleurs, notre recherche montre que, tous les autres facteurs restant inchangés, I'IDE reçu et les redevances payées sont des substituts réciproques par rapport à l'impact positif sur la PGF.

In this paper we examine the relationship between inward FDI and total factor productivity (TFP) in a framework motivated by the OLI paradigm. A panel data approach is used to study the effects of FDI and payments of royalties and license fees (R\&L) on aggregate TFP in a sample of 16 OECD countries, between 1985 and 2002. Our empirical tests show that FDI and R\&L have a positive impact on host-country TFP, and also suggest that the amount of positive effects of FDI and R\&L is dependent on the level of development of the receiving country. Additionally, our data show that, when other factors remain constant, inward FDI and R\&L payments are substitutes in positively influencing TFP of the host country. 
In recent years improved attention has been paid to the deep analysis of the effects of Foreign Direct Investment (FDI) (see, for example, Blomström and Kokko, 2003; and Görg and Greenaway, 2004). The main reason is that FDI often involves the transfer of knowledge from one country to another (e.g., Carr et al., 2001), making it a potentially important vehicle for international diffusion of technology ${ }^{1}$. As a matter of fact, theoretical models of foreign investment suggest that there should be a positive relationship between FDI and international diffusion of technology (Caves, 1974, 1996; Markusen, 1995). Knowledge will move through demonstration effects, labour turnover, or reverse engineering.

The positive effects predicted by theoretical models, and documented by some empirical studies, have been driving a considerable change in the attitude towards inward FDI over the last couple of decades, as most countries have liberalized their policies to attract investments from foreign multinational corporations (MNCs). Additionally, Mullen and Williams (2005) have studied the role of FDI in regional economic performance over the period 1977 to 1997 and have found that inward foreign investment has played a 'strong, vital role in regional economic activity' with significant effects on 'regional productivity and growth' (2005, p. 279). Accordingly, in the expectation that some of the knowledge brought by foreign companies may spill over to the receiving country's domestic firms, governments across the world have lowered various entry barriers and opened up new sectors to foreign investment. An increasing number of national governments also provide a variety of forms of investment incentives to encourage foreign owned companies to invest in their countries.

The economic rationale for offering special incentives to attract FDI frequently derives from the conviction that foreign investment produces externalities in the form of technology transfers and spillovers ${ }^{2}$. Romer (1993), for example, argues that there are significant 'idea gaps' between rich and poor countries, foreign investment being an important instrument in transferring technological and business know-how to poorer countries, with substantial spillover effects for the poorer economy as a whole.

But, in spite of the predictions of theoretical models, the empirical microeconomic and microeconometric literature on the occurrence of positive effects of inward FDI is, at best, controversial. If, on the one hand, early studies using industry-level data, such as Blomström and Persson (1983), find that foreign presence in an industry positively influences domestic labour productivity, and the earliest statistical analyses of inter-industry effects of FDI claim that technical progress did not only take place in the FDI own industries, but also in other sectors (Katz, 1969), on the other hand, some more recent studies using firm-level data are less supportive of the existence of positive spillovers ${ }^{3}$. Furthermore, some authors as Aitken et al. (1997) and Haddad and Harrison (1993) find that foreign investment has a negative effect on the performance of domestically owned firms. In addition, at a macroeconomic level, the evidence is not more conclusive. While some studies - using aggregate FDI flows for a broad cross-section of countries - have generally suggested a positive role for FDI in generating economic growth, particularly in environments where the capability of absorption matters (De Gregorio, 1992), other works using more sophisticated econometric methods (Carkovic and Levine, 2002; Alfaro et al., 2004; Chowdhury and Mavrotas, 2006) cast doubts about the optimistic conclusions of the first analyses ${ }^{4}$.

1 Of course, there are many other reasons why FDI has become a much-discussed topic. One of them is the dramatic increase in the global flow and the resulting rise in its importance as a source of investment funds for an increasing number of countries.

2 As it is well known, in absence of spillovers, there is no reason for policy to differentiate between FDI and other forms of investment, including domestic investment.

3 Of course there are some exceptions. Among them, we have the evidence from China's manufacturing sector provided by Chuang and Hsu (2004).

4 In addition, Lichtenberg and van Pottelsberghe de la Potterie (1996) have analysed the importance of FDI for 
As it is well known, some problems have affected the microeconomic empirical studies of inward FDI spillover effects. Firstly, because data problems are particularly acute with regard to service industries, most research on FDI at the firm level focuses exclusively on goods ${ }^{5}$. Secondly, empirical work on FDI is generally overwhelmed by the limited availability and quality of the data. As a result, empirical research on FDI at firm level is largely limited to firms from just a few countries. Furthermore if, as Cantwell (1989) and Aitken and Harrison (1999) argue, positive technology spillovers do not occur in all industries, the estimates of empirical studies at the firm level may be more or less biased, according to the type of industry included in the sample of firms. On the other hand, macroeconomic empirical studies had been criticized too. A great lot of the criticisms have been directed to their econometric grounds (Carkovic and Levine, 2002) ${ }^{6}$ and to the direction of causality in the relationship between FDI and economic growth (Kholdy, 1995; Chowdhury and Mavrotas, 2006).

However, the difficulty in finding robust empirical evidence to support the existence of positive spillovers can be associated to a more fundamental problem: researchers can be looking in the wrong place and with erroneous instruments. As a matter of fact, the macroeconomic evidence follows usually the framework of cross-country growth regressions, trying to explain the effect of FDI on per capita economic growth rate, this rate being typically measured in five-year periods. Our work uses a different framework. On the one hand, we follow Solow (2001) in considering that analysis shall focus more directly on TFP as the proper left-hand-side variable; on the other hand we use a descriptive framework motivated by the OLI paradigm, developed by Dunning (1981, 1988), and by the knowledge capital model (Markusen and Maskus, 1999) which require the inclusion within explanatory variables of one that controls the payment of royalties and license fees (R\&L).

Consequently, in face of the above-mentioned change in the attitude towards inward FDI over the two recent decades, given the limited guidance to the empirical work provided by the theory and the inconclusive results of the empirical literature on the relationship between FDI and economic growth, it is significant to examine whether the positive effects of FDI are strong and systematic enough to justify supporting foreign investment with fiscal and financial incentives. Particularly, if we are in face of both positive and negative spillovers, as some microeconomic empirical evidence seems to point, it is crucial to find out the net effect of inward FDI at country level.

Our work uses a descriptive framework and, based on it, investigates how foreign investment has affected the aggregate total factor productivity (TFP) of OECD countries. We use a panel data approach, which has the advantages mentioned by Görg and Strobl (2003), to estimate the elasticity of TFP in relation to inward FDI, to royalties and license fees (R\&L), and to the country's level of development. We also explore the interaction between inward FDI and R\&L.

The remainder of the paper is structured as follows: Section 2 discusses the relationship between FDI and productivity; section 3 reviews the FDI evidence on host-country growth, spillovers and learning. Section 4 introduces the conceptual framework that drives our analysis and presents a statistical model that helps to rationalize some possible linkages between FDI and TFP. Section 5 presents estimates on elasticities of TFP with respect to both FDI and R\&L. Section 6 deals with human capital as a possible channel of impact of level of development on TFP. Finally, section 7 concludes.

international diffusion of technology in thirteen OECD countries, with the same R\&D weighting approach that Coe and Helpman (1995) and Keller (1998) use for imports, and they do not find significant effects from inward FDI. 5 This lack of empirical research on FDI in the services sector is increasingly troublesome, owing to the growing importance of services in production, in trade, and in investment.

6 For example, Carkovic and Levine (2002) argue that the macroeconomic findings on growth and FDI must be viewed suspiciously, because existing studies do not fully control for simultaneity bias, country-specific effects, and the routine use of lagged dependent variables in growth regressions. 


\section{The relationship between FDI and productivity}

It is possible to identify three main channels through which inward FDI is thought to improve productivity of a host-country: a) direct improvement in efficiency through the redirection of local resources towards more productive uses, including within purchased firms; b) indirect impact via spillovers and other externalities associated with interactions between the foreign affiliate and the host country economy; and c) increase in domestic market competition. All the three channels can contribute to reduce the substantial gaps existing between countries.

The most obvious direct impact on productivity is through the reallocation of resources, including within firms, towards more productive activity. Since domestic firms are likely to have better knowledge and access to domestic markets, a foreign firm that decides to enter the market must have compensating advantages (Graham and Krugman, 1991). It seems likely that the foreign firms will benefit from advantages over domestic competitors deriving from some assets of the former like superior management skills, more advanced technology, and better access to international markets. Given the limited level of resources within the host economy, the entry of a foreign firm, whether by acquisition or physical investment, is likely to be associated with a shift of resources and effort away from a less productive activity. In this way, FDI is expected to make an increase in overall productivity within the economy possible. The dimension of the host country's benefits depends on the action of a large bulk of linkages between foreign owner(s) and domestic local firms and customers as well as on the effectiveness of the foreign firm to prevent the gains to be totally transferred to the host country's firms and consumers. For example, a foreign-owned firm may contribute directly to the productivity of domestic firms by lowering input costs, or by increasing the demand for inputs produced by local suppliers.

From the interactions with foreign affiliates, local firms can capture part of the benefits of the advantages of the former, this indirect impact being usually rationalized as positive externalities. Productivity spillovers from FDI take place when the entry or presence of multinational corporations increases the productivity of domestic firms in a host country, and the MNCs do not fully internalize the value of these benefits ${ }^{7}$. For example, local firms may learn with the practice of MNCs or MNCs may transfer cost-free technology and know-how to local suppliers in order to improve the quality of inputs (Rodriguez-Clare, 1996). Alternatively, local competitors might benefit by attracting employees with firm-specific knowledge from the foreign affiliate (Fosfuri et al., 2001). In case of vertical spillovers, that is, productivity spillovers that take place due to linkages between foreign firms and their local suppliers ${ }^{8}$ it can be impossible to prevent the action of positive externalities.

But the absorptive capacity of the host country matters. In essence, the idea is that the magnitude of spillover benefits is dependent on the ability and motivation of local firms to interact with, learn from, and invest in, the technology and ideas that are spilt by the foreign firm. It is usually alleged that spillovers will only accrue if the technology, knowledge or any other 'gap' between foreign and local firms is not too large. However, the importance of relative backwardness is theoretically controversial. While Findlay (1978) suggests that the greater the distance between two economies in terms of development, the greater the accumulation of available opportunities to take advantage of in the less advanced economy, and so the greater the pressure for change and the more fast the assimilation of new technology, Glass and Saggi (1998) argue that the larger the gap, the lower the quality of the technology transferred and the lower the potential for spillovers.

The entrance of foreign affiliates is usually seen as a way of strengthening domestic market competition, thereby leading eventually to higher productivity, lower prices and more efficient resource allocation, but it can also lead to greater market concentration and reducing domestic 
market competition. The risk of the latter is exacerbated not only if the entrant has an important international market position, if the barriers to entry into the industry are high, but also because of host country characteristics: either a small market or markets unconnected geographically, competition laws weak or weakly enforced (OECD, 2002). So, the increase in domestic market competition is not always an assured outcome of the FDI entry, and where that outcome is achieved it can be either reduce the productivity of domestic firms as suggested by Aitken and Harrison (1999) and Konings (2001), or have positive effects as noted by Kokko (1996) and Driffield (2001). In order to assess the dimension of direct and indirect effects of FDI on productivity, and in face of possible contradictory effects of market competition, there is a large ground for empirical investigation, both at the micro and at the macro level.

\section{Empirical evidence}

As was clarified in the previous section there could be effects of FDI on productivity without the presence of spillovers. However, the empirical literature on growth effects of FDI, both at a macroeconomic level and at a microeconomic level, relies almost exclusively on the occurrence of spillovers from foreign owned to domestically owned firms. A complete review of empirical literature on FDI spillovers is outside the scope of this paper, which aims both at emphasizing some useful aspects to support the descriptive framework that we shall use as a basis of empirical work and to show the utility of a rationale like ours. Readers interested in a critical assessment of the role of FDI should see Blomström and Kokko (1998), or Görg and Greenaway (2004) and Pessoa (2008) if interested in more recent reviews.

Empirical microeconomic literature on productivity spillovers of FDI is abundant and varied (Castellani and Zanfei, 2006). For simplicity we can separate them in two types: case studies and statistical analyses. Case studies are specifically useful in describing the actual linkages between multinationals and host country players such as the particular forms assumed by technical assistance, control of quality, management training, and organization of the production process that are key aspects of the interaction of MNCs with their local suppliers (Moran 2001). The cases studied by Mansfield and Romeo (1980) and Rhee and Belot (1990), for example, illustrate various channels through which spillovers are assumed to occur, with a particular emphasis on technology transfer to domestic firms. Case studies have also documented the importance of local skills and in-house technological capacity to adapt and use techniques developed elsewhere (Lall, 1992; Evenson and Westphal, 1995; Ariffin and Figueiredo, 2004).

In general, case studies have shown significant positive FDI spillovers. For example, Larrain et al. (2000) show substantial spillover benefits for the local economy generated by Intel's investment in Costa Rica in 1997 (specifically, creating new training programmes in higher education institutions; producing important signalling effects on other investors; and attracting new suppliers to Costa Rica) ${ }^{9}$. However, the evidence from case studies is inconclusive. On the one hand it is, at best, mixed. On the other hand, case studies do not always offer quantitative information and do not easily generalize.

The mixed nature of evidence can frequently be seen. For example, Rhee and Belot (1990) suggest that foreign entrants led to the creation of booming domestic textiles industries in Mauritius and Bangladesh. In contrast, Mansfield and Romeo (1980) surveyed 26 US-based MNCs and reported that in only a few cases had FDI accelerated the access of local competitors to new technology. Likewise, the conclusion about the Intel's investment in Costa Rica made by Hanson (2001) is very different from the one of Larrain et al. (2000). In face of the drawbacks of case studies, the research is usually based on industry-level and micro-level studies and is done 
through statistic analyses searching horizontal and vertical productivity spillovers, using either cross-section or panel data.

The literature on horizontal and vertical spillovers was recently surveyed by Görg and Greenaway (2004). These authors analyzed 42 studies (16 with cross-sectional data and 26 with panel data) on horizontal productivity spillovers in manufacturing industries in developed, developing and transition economies. In the 26 studies which employ panel data, the most appropriate estimating framework as was argued by Görg and Strobl (2003), surveyed by these authors only eight studies find unambiguously positive evidence and are almost all of them for developed countries, seven show evidence of negative effects of MNCs on host-country firms and the remainder present mixed or statistically insignificant results. Görg and Greenaway (2004) also surveyed studies on vertical spillovers and among the five studies using panel data only two indicate positive and statistically significant results: the one of Smarzynska (2004) with evidence for backward spillovers and the other made by Driffield et al. (2002) searching for forward spillovers.

As firm-level studies of particular countries (e.g., Germidis, 1977; Aitken and Harrison, 1999) fail in finding evidence of positive technology spillovers from foreign firms to domestically owned ones, several authors (e.g., Wheeler and Mody, 1992; Harrison, 1996, Aitken et al., 1997; De Mello, 1997; Carkovic and Levine 2002) are driven to conclude that there are no reasons to believe that FDI accelerates overall economic growth. However, the absence of spillovers verified at a micro level is not sufficient to discard the positive influence of FDI on TFP. This non-appearance may be due to several reasons, among them, for example, it can be the result of a selection bias or the influence of FDI on TFP can be the resulting effect of reallocation of resources and not the result of spillovers measured at the firm level. In these cases a macroeconomic analysis is more adequate to show the global effect of FDI.

At a macroeconomic level, the influence of FDI on the host country growth has been studied through wide-ranging cross-country studies in which the rate of growth of real GDP or GDP per capita is related to the inward flow (or stock) of FDI. A pioneer study in using aggregate FDI flows for a broad cross-section of countries was done in the context of the convergence controversy and has put forward a positive role for FDI in generating economic growth (Blomström, et al., 1994). These authors have found that, among developing countries, from 1960 to 1985, ratios of FDI inflow to GDP in a five-year period were positively related to growth in the subsequent five-year period. However, when the authors divide the sample in two groups this positive effect only remains for countries with the higher income within the group of the developing countries.

Other empirical investigations have shown that FDI promoted growth only in some groups of countries, and have put forward some possible explanations for that fact: the growth effects of FDI are associated to contexts where there is higher capability of absorption, where some specific type of trade policy was implemented, or where education has attained some minimum threshold (de Mello, 1997; Kottaridi, 2005). In relation to the host country trade policies Bhagwati (1978), suggested that the growth effects of inward FDI could be positive or adverse, depending on the type of trade policy used: the effectiveness of FDI in encouraging growth would be improved by an export promotion policy and diminished by an import substitution policy ${ }^{10}$. Other authors emphasize the capability of absorption (De Gregorio, 1992). In some studies, as in the extensively quoted paper of Borensztein et al. (1998), which use a dataset of FDI flows from industrialized countries to sixty-nine developing countries, it is found that FDI is an important vehicle for transferring technology and higher growth only when the host country has a minimum threshold of highly educated workforce that allows it to exploit FDI spillovers ${ }^{11}$. This explanation 
is partly endorsed by Alfaro et al. (2004), in a regression analysis for the period 1975-1995 as a whole, who have found little support to the idea that FDI has an exogenous positive effect on economic growth, but they show that host country conditions, such as the level of education, play an important role in allowing the positive effects of FDI to materialize. But these authors add another factor, which allegedly play a key role: the development of local financial markets.

Recently Carkovic and Levine (2002), using new statistical techniques and two new databases to re-examine the relationship between economic growth and FDI, find that FDI inflows do not exert an independent influence on economic growth over the entire period, 1960-1995. Hence, these authors put forth that FDI inflows show no more than sporadically significant effects in five-year periods. They also find that none of the variables used in precedent studies consistently determine the effect of FDI on growth, even if some of them are statistically significant in some recipe of controlling variables.

To sum up, as with the microeconomic studies of productivity spillovers, those of the effects of FDI inflow on economic growth are inconclusive. Almost all find positive effects in some periods, or among some groups of countries ${ }^{12}$, in some specifications, but one cannot say from these studies that there are universal impacts of FDI on growth (Lipsey, 2002). So, it is time to try to identify the FDI effects on productivity with a different framework. One empirical finding is particularly important in the context of our present work. De Mello (1999), in a panel data study of aggregate country effects, found that FDI inflows raised growth through different channels, according the country's level of development. In developed countries, FDI inflows increased TFP growth, but not fixed investment, while in developing countries it raised fixed investment, but not TFP growth. Our paper searches the relationship between FDI and TFP in a sample of developed countries.

\section{Descriptive framework}

How does one come to know whether the amount of inward Foreign Direct Investment measures anything interesting concerning diffusion of technology? One possibility is to search the effects of FDI on economic growth, adopting a cross-section view as in figure 1. In this figure we scatter the FDI/GDP ratio against GDP per capita growth. This is the most commonly used approach to carry out macroeconomic FDI empirical tests (De Gregorio, 1992; Balasubramanyam, et. al., 1996; Borensztein, et al., 1998; Alfaro, et al., 2004). The main reasons alleged for this procedure are that FDI can offer an incentive to competition, bring with it savings and innovation, increase capital formation, and through these effects lead to job creation and economic growth.

\section{Figure 1 - FDI and growth of GDP per capita}

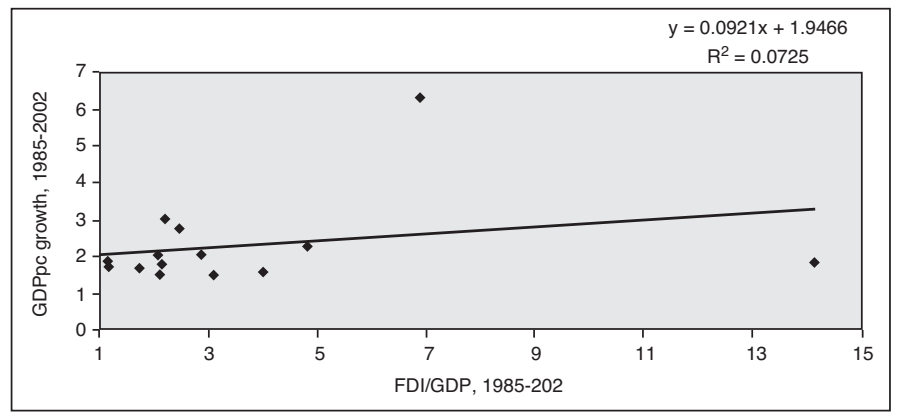

Source: World Bank (2004)

12 For example. Campos and Kinoshita (2002) find positive growth effects of FDI among 25 Central and Eastern European and former Soviet transition countries. 
However, this is not a consensual outcome of theory. For example, Brecher and Diaz-Alejandro (1977), Brecher (1983), Boyd and Smith (1992), predict that in the presence of pre-existing trade, price, financial, and other distortions FDI will harm resource allocation and decrease growth. Accordingly, theory produces ambiguous predictions about the growth effects of FDI and therefore an econometric assessment of growth effects must control all the above-mentioned, and possibly other, distortions. So, figure 1 shows that the correlation between FDI and per capita growth is near zero. This is not an unexpected result, given the empirical evidence reviewed in the previous section.

The path we follow in this work is not to search correlations between FDI and GDP per capita growth rate (which depends on a lot of factors, with some of them demand driven, if rates are calculated in five years periods as is usual in empirical studies) but to look for correlations between FDI and TFP. Figure 2 depicts data on average of both inward FDI and TFP in a sample of 17 OECD countries from 1985 to $2002^{13}$. Like figure 1, Figure 2 also shows the equation of regression and the adjusted trend line.

As is apparent from the comparison between figure 1 and figure 2 the correlation is much more significant between FDI and TFP than between FDI and the growth rate of GDP per capita. Furthermore, figure 2 shows that the association between FDI and TFP is likely to be not linear: in general an increase in the index of FDI is associated to an increase in the index of TFP, though the latter increases with a decreasing rate. Of course figures 1 and 2 are not directly comparable, because while in the former each point corresponds to a pair of FDI and GDP per capita growth for a given country, in the latter each point corresponds to the sample average of FDI and TFP in a given year, and there is a lot of heterogeneity among countries. But our data show that the association between FDI and TFP is stronger than the association between FDI and the growth rate of GDP per capita at the country level, too ${ }^{14}$.

\section{Figure 2 - Association between TFP and Inward FDI}

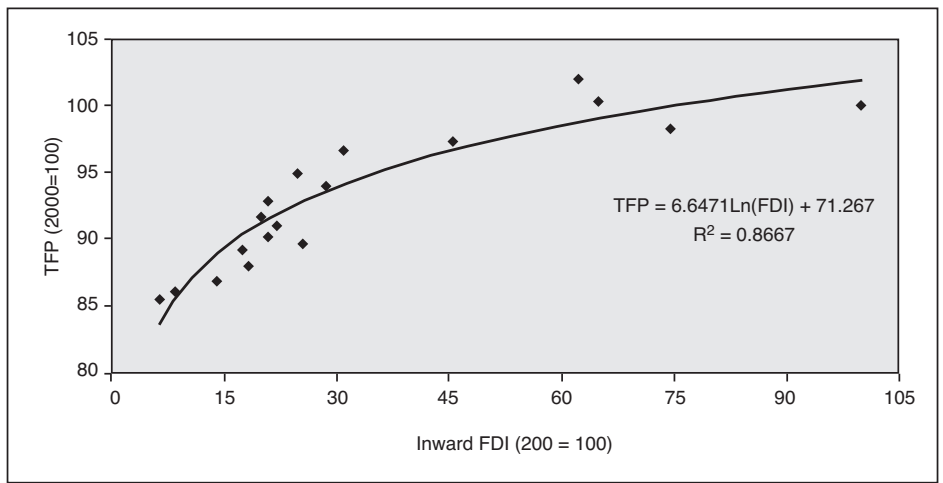

Source: World Bank (2004) for FDI and OECD (2004) for TFP

What are the reasons to hypothesize that an increase in inward FDI is associated to an increase in TFP, and to think that this relationship must be stronger than the one between FDI and GDP per capita growth? In order to answer this question, it is useful to introduce figure 3, which basically allows a more detailed discussion of the underlying assumptions of correlations between FDI and TFP. 
Figure 3 illustrates the main influences in TFP associated to foreign multinational corporations (MNCs), which we shall review. We assume that through FDI and royalties and license fees (R\&L) MNCs contribute to international diffusion of technology and this affects Total Factor Productivity $\left(\right.$ TFP $_{t}$ ) of a host country in $t$ period because it promotes learning ${ }^{15}$ and generates spillovers. But figure 3 depicts another FDI impact on TFP: the reallocation of resources, a channel to which scarce attention has been paid in empirical literature.

\section{Figure 3 - FDI and TFP}

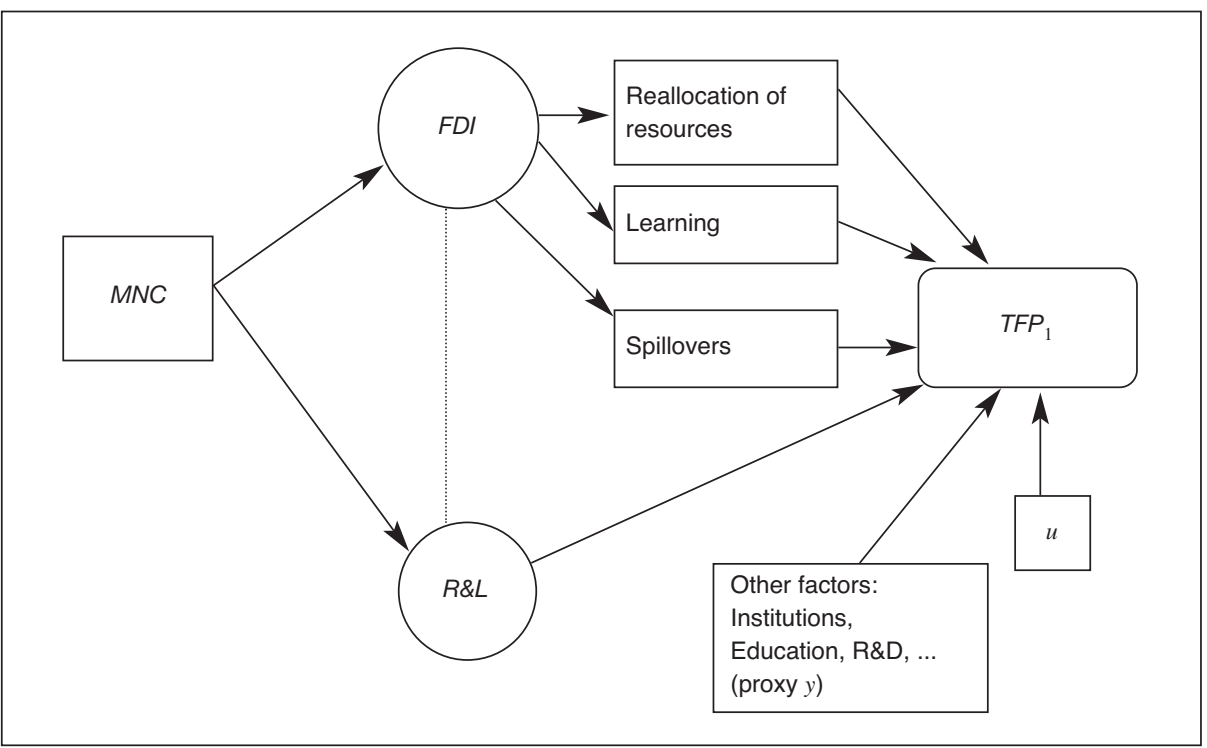

As we have seen in section 2, the most common theoretical justification for the existence of spillovers is that overseas investors possess certain advantages that local firms can capture through their interactions with foreign affiliates. For example, local firms may learn with the practice of MNCs or MNCs may transfer technology and know-how to local suppliers in order to improve the quality of inputs (Rodriguez-Clare, 1996). Alternatively, local competitors might benefit by attracting employees with firm-specific knowledge from the foreign affiliate (Fosfuri et al., 2001). Local firms that are customers of the foreign affiliate may also benefit from the supply of more sophisticated intermediate inputs. For the host country, these benefits derive from the intentional development of forward and backward linkages between local and foreign firms, as well as from the accidental leakage of knowledge and technology to competing and unrelated firms.

There is a huge literature highlighting the central role of MNCs as producers and disseminators of knowledge and technological innovations (e. g., Teece, 1977; Cantwell, 1989; Narula, 2003) ${ }^{16}$. A vast literature also deals with ownership, location and internalization - the OLI paradigm developed by Dunning $(1981,1988)$ - and with the knowledge capital model (Markusen and 
Maskus, 1999) and horizontal multinational firms. This literature explains the internalization decision between FDI and licensing. In some cases MNCs transfer technologies of new vintages through direct investment and they license or transfer their older technologies through joint ventures (Mansfield and Romeo, 1980). But, because MNCs often choose to internalize some part of their transactions, their importance for an economy can be underestimated if we rely only on the figures of FDI flows as carriers of international diffusion of technology, as is usually done by the empirical literature on the growth effects of FDI. In other words, MNCs may influence the TFP of a host country through FDI, trough licensing or both.

The most significant part of the literature on MNCs emphasizes technology as a driving force for the internationalization of the operations of such firms. As powerful as technology might be in driving the internationalization of firms, it is not the only intangible asset that firms may seek to exploit worldwide. Patents and copyrights can convey obvious competitive advantages to the firm that holds them. In some industries, the assets are in the form of brand names for which worldwide consumers are willing to pay a premium (for example, cola beverages). Firms owning such assets can, of course, license country-specific production rights, rather than choose to invest in foreign production facilities. Accordingly, it is because FDI flows alone do not tell the whole story about the transfer of technology and other intangible assets that we introduce, among the determinants of TFP in figure 3 , the royalties and license fees (R\&L) paid by the authorized use of intangible, non-financial, non-produced assets and proprietary rights, such as patents, copyrights, trademarks, franchises and industrial processes. The inclusion of R\&L is also adequate to show that the possible ways in which the advantages possessed by MNCs can be internationally transferred fall between the two extremes represented by licensing to an independent firm, an example of arms length transaction, and intra-firm transfer.

From an MNC viewpoint, both modes of transfer have their advantages and disadvantages. For example licensing to an independent firm will be convenient when the licensor lacks some assets other than the intangibles which are required for FDI, such as capital, a widespread trade and support network, and so on. Also, licensing decreases the risks deriving from political changes in the host-country (for example expropriation), and it has a shorter lead-time than starting a subsidiary from the beginning. On the other hand intra-firm transfer avoids any outflow of technology to other firms and it is more favourable than licensing when arms length transactions are complex and difficult to enforce. Another situation in which intra-firm transfer is convenient with respect to licensing arises as a consequence of the transfer process itself, namely in the presence of no negligible transfer costs ${ }^{17}$. A policy designed to attract FDI must have these points in consideration, because they condition the amount of incentives offered and the resulting effect on TFP.

Productivity spillovers may take place when local firms improve their efficiency by copying technologies of foreign affiliates operating in the local market either based on observation or by hiring workers trained by the affiliates. These are knowledge spillovers in nature. Another kind of spillovers occurs if multinational entry leads to more severe competition in the host country market and forces local firms to use their existing resources more efficiently or to search for new technologies (Blomström and Kokko, 1998). Although this distinction must be done for policy purposes because knowledge spillovers present a rationale for government action to subsidise FDI inflows, and such rationale is absent when the improved productivity of local firms is due to increased competition, for our general endeavour such distinction may be negligible. Equally negligible, for our present purposes, is the division between horizontal and vertical spillovers, although MNCs behaviour may be different in face of each one of them, if MNCs try to prevent technology leakage and spillovers from taking place. In general, this goal can be achieved through diverse ways: formal protection of their intellectual property, trade secrecy, paying higher wages or locating in countries characterized by limited imitative capacities of their domestic firms. 
However, to prevent the occurrence of spillovers through these instruments is much easier in the case of horizontal spillovers.

Of course that other than the above mentioned factors affect TFP: institutions (Narula and Dunning, 2000; Mudambi and Navarra; 2002), skilled labour (Coughlin and Segev, 2000; Keller, 1996), technological capacity (Glass and Saggi, 1998), infrastructures (Coughlin et al., 1991) developed financial markets (Alfaro et al., 2004), and so on. All these factors are associated to the level of development that country $i$ enjoys. So, we assemble all these factors in a single variable, $y_{i t}$, termed level of comparative development. The inclusion of these factors in a single proxy is also justified because there is not an unambiguous theory of the comparative importance of each one of those factors. One the other hand, assembling all those factors in a single proxy allows us to focus our attention on the FDI and R\&L variables, which are the main endeavour of our investigation. Furthermore, the importance of comparative development is highlighted in several analyses of individual host countries and in various statistical analyses. Although that importance had been more stressed in the context of developing countries (e.g., Blomström et al., 1994; Balasubramanyam, 1998) than for advanced countries, a lot of other evidence points to the importance of comparative level of development. For instance, among the studies employing panel data that report unambiguous positive FDI effects the vast majority is related to developed countries: United States (Keller and Yeaple, 2003); United Kingdom (Liu et al., 2000; Haskel et al., 2002); Ireland (Görg, and Strobl, 2003). In contrast, studies using firm level panel data find evidence of negative effects only in transition economies and developing countries: Bulgaria (Konings, 2001); Czech Republic (Djankov and Hoekman, 2000); Venezuela (Aitken and Harrison, 1999), for instance.

A number of extreme simplifications were made in drawing figure 3 and in defining the various terms. In the centre of figure 3 there are three unobservable variables: reallocation of resources, learning and (other) spillovers that are affected by $F D I$ and that we presume affect $T F P_{t^{*}}$. But, as reallocation, learning and spillovers are very difficult to measure we shall compute the effect of the activities behind such variables. Figure 3 is a statistical descriptive framework rather than a 'theory' of FDI. It indicates that fact by adding an error $u$ to the determinants of TFP, in this way making the explanatory variables imperfect measures of TFP ${ }^{18}$. For example, FDI and $R \& L$ are taken as exogenous but, if as it is likely, $F D I$ is correlated with $R \& L$, then one might expect feed back in subsequent periods, making the relationship between TFP and FDI much more complex. So, what is depicted in figure 3 is, at best, a very crude reduced-form-type relation whose theoretical underpinnings have still to be worked out. But one has to start someplace. Nevertheless, figure 3 does provide a scheme to discuss much of the research in the effects of FDI and to estimate some relevant elasticities. It is also a first step towards the test of the Internalization thesis, a subject that has received scant attention in empirical literature. To our knowledge, ours is the first work to search simultaneously the empirical effects of FDI and R\&L on TFP.

\section{Empirical tests: FDI and R\&L}

Our empirical work estimates the impact of FDI and R\&L on TFP, for the period between 1985 and 2002, in a panel data of 16 OECD economies: Australia, Belgium, Canada, Finland, France, Germany, Greece, Ireland, Italy, Netherlands, Japan, Portugal, Spain, Sweden, United Kingdom, and United States. We are conscious about the reduced number of countries, but the lack of TFP data prevents the use of a more extended sample. In the empirical tests we use the following variables and data, for the country $i$ and the time $t$.

18 A 'theory' would have to be explicit about the conditions (economic, technological, and legal) under which the benefits of MNCs are transformed in TFP. Such a theory would start with the underlying notions of learning and spillovers and with the more precise mechanism driving the effects of FDI on TFP and likely feedbacks. Furthermore, a theory would have to be able to give an unambiguous explanation to the patent change in attitude towards FDI over the last couple of decades, as most countries have liberalized their policies to attract foreign investments. 


\begin{tabular}{|c|c|c|}
\hline & Variables & Data sources \\
\hline $\mathrm{TFP}_{i t}$ & Total factor productivity; & OECD (2004) \\
\hline $\mathrm{FDI}_{i t}$ & Foreign Direct Investment, net annual inflows ${ }^{19}$ & World Bank (2004) \\
\hline $\mathrm{RL}_{i t}$ & Annual payment to the exterior of $R \& \mathrm{~L}^{20}$ & World Bank (2004) \\
\hline $\mathrm{Y}_{i t}$ & $\begin{array}{l}\text { GDP per capita of country i over USA GDP per capita } \\
\text { (PPP at constant } 1995 \text { international \$). }\end{array}$ & World Bank (2004) \\
\hline $\mathrm{RRD}_{i t}$ & $\begin{array}{l}\text { Number of Researchers in R\&D per million of active people, } \\
\text { expressed in full-time equivalent (FTE). }\end{array}$ & World Bank (2007) \\
\hline
\end{tabular}

Notes: TFP was calculated by the OECD for the purpose of international comparisons and it is based on harmonized prices for ICT capital goods (OECD, 2004). The annual values of FDI and RL, are from World Development Indicators and are collected from Balance of Payments at current US\$ (World Bank, 2004). TFP, FDI and RL are converted by us to index numbers (base year $=2000)$.

In order to begin, it is helpful to write down the simplest possible model that might connect the first three variables of table 1 , in natural logarithm form, in the spirit of figure 3 :

$$
\operatorname{LnTEP}_{i t}=\beta_{0 i t}+\beta_{1} \operatorname{LnFDI}_{i t}+\beta_{2} L_{n R L_{i t}}+u_{i t}
$$

Equation (1) is formalized assuming that TFP is independent of the level of comparative development of country $i$. The equation is estimated in a panel of data (an unbalanced panel because of some missing values for the variables), using some distinct techniques. As it is well acknowledged, the key advantage of the panel data models is its increased precision of the estimators, in confront with cross-section models. However, in panel estimation, the number of underlying assumptions grows correspondingly. In fact, equation (1) can be estimated by several methods, according to assumptions about: i) the intercept $\left(\beta_{0 i t}\right)$; and ii) the relationship between the independent variables and the error term $\left(u_{i t}\right)$.

Respecting to i) and apart from the case of no intercept, that is $\beta_{0 i t}=0$, three alternative specifications can be built, based on three key assumptions: a) identical intercept for all countries $\left(\beta_{0 i t}=\beta_{0}\right)$, which results from an estimation technique with a common constant; b) a different intercept estimated for each country $-\beta_{0 i t}=\beta_{0 i}$, with $E\left(\beta_{0 i} u_{i t}\right) \neq 0-$ the well-known fixed effects estimator; c) intercepts estimated as random variables across countries. $-\beta_{0 i t}=\beta_{0}=v_{i}$ with $E\left(v_{i} u_{i t}\right)=0$, that is, assuming that and errors are uncorrelated) - the so called random effects model.

Usually, it is assumed the superiority of models with Fixed Effects (FE) and models with Random Effects (RE) over pooled models with a common constant. On the other hand, researchers typically apply some tests as a means of disentangling, between FE and RE, the most accurate method to deal with the considered data. In this paper, we shall follow a different path owing to three main reasons.

19 Foreign direct investment is net inflows of investment to acquire a lasting management interest (10 per cent or more of voting stock) in an enterprise operating in an economy other than that of the investor. It is the sum of equity capital, reinvestment of earnings, other long-term capital, and short-term capital as shown in the Balance of Payments.

20 Royalties and License Fees are payments between residents and non-residents for the authorized use of intangible, non-produced, non-financial assets and proprietary rights (such as patents, copyrights, trademarks, industrial processes, and franchises) and for the use, through licensing agreements, of produced originals of prototypes (such as manuscripts and films). 
First, we need to know if there is some non-observable country heterogeneity, that is, heterogeneity in the explanation of TFP variation not controlled by the independent variables. This implies the need of admitting the absence of such heterogeneity, which is made in estimation models with a common constant. This means to discard the a priori assumption of FE and RE superiority, and to choose between a common constant's model for all economies and a model based on specific fixed effects for the cross-section of countries. Accordingly, we will test these two hypotheses.

Second, there is a lot of evidence pointing to the fact that unobservable and time constant factors are, at least partially, associated to the locational characteristics of the country (Wheeler and Mody, 1992; Brainard, 1997). Such locational factors can determine a geographical dimension of positive vertical spillovers (Sjöholm, 1999; Kugler, 2000), and can also be associated to other less time-variant characteristics of the host country like policy preferences ${ }^{21}$. So, this evidence points to the fact that country heterogeneity is not random.

Third, our panel is unbalanced, what means that some observations are missing so that $T_{i}$ varies among cross-sections. In this case, RE model has an important drawback relatively FE: typically, computer econometric packages (as is our case with program Eviews 3.1) use the largest value of $T_{i}$ in computing the variance estimates. This procedure is consistent only if the number of missing observations is asymptotically negligible. Obviously, this is not our case, where are missing 47 , and 115 when human capital is introduced, in a balanced panel number of 288 . So, for all the above reasons, we do not consider the RE hypothesis ${ }^{22}$. In the present paper, we will begin by estimating a model with a common constant and another with fixed effects and, after that, we will apply a test in order to decide which one provides more reliable estimates.

Respecting to ii), that is the relationship between the dependent variables and the error term $\left(u_{i t}\right)$, we will calculate estimates using three different methods, according some assumptions of the classical least squares method (homocedasticity, no serial or contemporaneous correlation) are respected or violated. Consequently, in table 2 we present the estimates calculated by system OLS (Ordinary Least Squares) method, whereas the subsequent tables show estimates that result from GLS (Generalized Least Squares) and SUR (Seemingly Unrelated Regression).

As above-mentioned, in table 2 we show estimates that are calculated by system OLS. Some of them are based on a regression with a common constant (columns 1, 2, 3 and 4), whereas others (columns 1', 2', 3' and 4') are resulting from a fixed effects model, that is, with a specific constant for each one country.

With a common constant, the estimates presented in column 1 show statistically significant positive elasticities of TFP in order to both $F D I$ and $R \& L: 1$ percent increase in FDI is associated with an increase in TFP of 0.029 per cent, and 1 percent increase in R\&L implies a percent increase in TFP of 0.054 . The $t$ tests indicate that the coefficients are significant at the 1 per cent level and the adjusted coefficient of determination $\left(\bar{R}^{2}\right)$ shows that the equation (1) explains more than fifty percent of the TFP variation.

However, the estimates shown in column (1) may be biased owing to the assumption implicit on the estimation method that the behaviour of the economy is time and cross-section invariant. But if the behaviour of the OECD economies varies in both dimensions, one form of getting away the total homogeneity of time and country behaviour assumed is to admit that elasticities are equal in every sample economy, but that there is some heterogeneity embraced by the constant in the regression, which becomes specific to each one of the countries. In this procedure, known as

21 For instance some countries, like Japan, have a long history of aggressively encouraged licensing of foreign technology at the same time that they restrict the operation of wholly owned subsidiaries of MNCs while others have had a much more non-discriminating behaviour.

22 The random effects approach has other considerable shortcoming. For instance, there is little justification for treating the individual effects as uncorrelated with the other regressors. 


\begin{tabular}{|c|c|c|c|c|c|c|c|c|}
\hline & (1) & $\left(1^{\prime}\right)$ & (2) & (2') & (3) & $\left(3^{\prime}\right)$ & (4) & $\left(4^{\prime}\right)$ \\
\hline $\begin{array}{l}\text { Common } \\
\text { constant }\end{array}$ & $\begin{array}{c}4.22^{\star} \\
(123.4)\end{array}$ & --- & $\begin{array}{c}4.07^{*} \\
(187.47)\end{array}$ & --- & $\begin{array}{l}4.132^{*} \\
(41.89)\end{array}$ & --- & $\begin{array}{c}2.993^{*} \\
(14.581)\end{array}$ & -- \\
\hline F. Effects & --- & a) & --- & a) & --- & a) & --- & a) \\
\hline LnFDI & $\begin{array}{l}0.029^{*} \\
(7.93)\end{array}$ & $\begin{array}{l}0.024^{*} \\
(7.60)\end{array}$ & $\begin{array}{l}0.095^{\star} \\
(21.79)\end{array}$ & $\begin{array}{l}0.063^{*} \\
(9.37)\end{array}$ & $\begin{array}{c}0.0299^{*} \\
(7.84)\end{array}$ & $\begin{array}{l}0.023^{*} \\
(8.68)\end{array}$ & $\begin{array}{l}0.460^{*} \\
(8.998)\end{array}$ & $\begin{array}{l}0.115^{\star *} \\
(2.16)\end{array}$ \\
\hline LnRL & $\begin{array}{l}0.054^{*} \\
(7.38)\end{array}$ & $\begin{array}{l}0.056^{*} \\
(8.72)\end{array}$ & $\begin{array}{l}0.095^{*} \\
(18.12)\end{array}$ & $\begin{array}{c}0.076^{*} \\
(12.45)\end{array}$ & $\begin{array}{l}0.052^{*} \\
(7.71)\end{array}$ & $\begin{array}{l}0.041^{*} \\
(9.47)\end{array}$ & $\begin{array}{l}-0.0144 \dagger \\
(-0.2294)\end{array}$ & $\begin{array}{c}-0.117^{\star *} \\
(-2.33)\end{array}$ \\
\hline LnFDI*LnRL & --- & --- & $\begin{array}{l}-0.017^{*} \\
(-14.66)\end{array}$ & $\begin{array}{l}-0.009^{*} \\
(-6.26)\end{array}$ & --- & --- & --- & --- \\
\hline Lny & --- & --- & --- & --- & $\begin{array}{l}0.022 \dagger \\
(1.108)\end{array}$ & $\begin{array}{l}0.325^{*} \\
(9.18)\end{array}$ & $\begin{array}{c}0.295^{\star} \\
(6.0592)\end{array}$ & $\begin{array}{l}0.234^{*} \\
(4.49)\end{array}$ \\
\hline LnFDI*Lny & --- & --- & --- & --- & --- & --- & $\begin{array}{l}-0.1016^{*} \\
(-8.446)\end{array}$ & $\begin{array}{c}-0.021^{\text {** }} \\
(-1.74)\end{array}$ \\
\hline LnRL*Lny & --- & --- & --- & --- & --- & --- & $\begin{array}{l}0.0147 \dagger \\
(0.9805)\end{array}$ & $\begin{array}{l}0.038^{*} \\
(3.10)\end{array}$ \\
\hline $\mathrm{T}$ & 18 & 18 & 18 & 18 & 18 & 18 & 18 & 18 \\
\hline $\mathrm{N}$ & 16 & 16 & 16 & 16 & 16 & 16 & 16 & 16 \\
\hline Obs & 241 & 241 & 241 & 241 & 241 & 241 & 241 & 241 \\
\hline$F$ test & 163.27 & 1078.02 & 161.47 & 605.91 & 109.206 & 714.022 & 94.93 & 362.95 \\
\hline $\bar{R}^{2}$ & 0.58 & 0.83 & 0.67 & 0.85 & 0.58 & 0.87 & 0.67 & 0.87 \\
\hline $\begin{array}{l}\text { Joint } \\
\text { significance F }\end{array}$ & \multicolumn{2}{|c|}{$F_{15,223}=21.699$} & \multicolumn{2}{|c|}{$F_{15,222}=16.603$} & \multicolumn{2}{|c|}{$F_{15,222}=31.374$} & \multicolumn{2}{|c|}{$F_{15,220}=22.241$} \\
\hline
\end{tabular}

Source: Calculations based on OECD (2004) and World Bank (2004).

Notes: a) For saving space, the country specific effects are not reported in the table, but they are available from the author on request. $t$ tests are shown in brackets: *significant at the 1 percent level; ${ }^{*}$ significant at the 5 percent level; ${ }^{\star * *}$ significant at the 10 percent level; †not significant. Standard errors and covariance matrix are White (1980) heteroscedastic corrected.

fixed effects model, individual country effects result from several unobservable and time-constant factors. So, table 2 presents estimates using the fixed effects model for equation (1) also. For space-saving reasons, the country specific effects are not reported in the table, but they are available from the author on request. As predicted, allowing for country specific fixed effects has turned the estimates of the elasticity in order to FDI lower and the elasticity in order to $R \& L$ higher, but both coefficients remain significantly positive. On the other hand the consideration of the fixed effects increase the explicative power of the equation, as measured by $\bar{R}^{2}$.

An important question, which emerges from figure 3 , is the nature of the relationship between FDI and R\&L. Are they complements or substitutes in influencing TFP? In order to answer to question we run the regression (1) with an interaction term $-L n F D I^{*} L n R L$. The estimates, included in column 2 e 2', show that all the coefficients are statistically significant and have the predicted sign. Particularly the negative sign of the interaction term shows that FDI and R\&L are substitutes in influencing TFP. 
However, the estimates shown in columns 1 and 2 and 1' and 2', based on equation (1), may omit some relevant variables. The most obvious candidate is the level of development of the country $i$ relatively to the technological frontier, as was depicted in figure 3 . This is consistent with models that have addressed the hypothesis that the host country's level of technical development may matter as a starting point (Findlay, 1978; Glass and Saggi, 1998). Furthermore, if spillovers should not be expected in all kinds of industries, the level of technological development of the host country matters. In particular, in countries with a low level of development, foreign MNCs may sometimes operate in 'enclaves', where neither products nor technologies have much in common with those of local firms. In such circumstances, there may be little scope for learning, and for spillovers to occur.

With these considerations in mind, it is now the time to introduce other relevant variables in the framework, as depicted in equation (2):

$$
\begin{aligned}
& \operatorname{LnTFP}_{i t}=\beta_{0 i t}+\beta_{1} L_{n F D I}+\beta_{2} L_{n R L_{i t}} \\
& +\beta_{3} L_{n y} * \operatorname{LnFDI}_{i t}+\beta_{4} L_{n y} * L n R L_{i t}+\beta_{5} L n y_{i t+} u_{i t}
\end{aligned}
$$

Equation (2) adds to equation (1) the level of comparative development of the country $i$ in log scale $\left(L n y_{i t}\right)$ and two interaction terms $L_{n y}{ }_{i t}{ }^{*} L n F D I_{i t}$ - interaction between the level of development and $F D I$, and $L n y_{i t}{ }^{*} L n R L_{i t}$ - interaction between the level of development and $R L$. If FDI is a carrier to the coming in of technology, we expect that the lower the country's technological level is the larger the positive effects of FDI would be. Hence, resulting a negative sign for coefficient on interaction variable $-L_{n} y_{i t}{ }^{*} L n F D I_{i t}$. On the other hand, we expect a positive sign of the interaction term between development level and $R L$ indicating that the increase of the development level will lead to a larger benefit of technology use licenses, perhaps as a consequence of the improved benefit of complementarity among technologies.

So, table 2 shows also in columns 3 and 3 ' and 4 and 4' the elasticity's behaviour in face of the level of comparative development and the interaction between this level and the basis variables. The introduced modifications have implied some alterations in the estimated coefficients. Let us begin by the estimation without interaction terms (columns 3 and $3^{\prime}$ ). Estimates show the expected signs independently of the method of estimation. The elasticity of TFP in order to FDI and the elasticity of TFP in relation to $R L$ are both, in general, lower than in previous specifications, but their signs remain positive. The estimates show, whatever the estimation method was, that everything else constant, and without interaction terms 1 percent increase in $F D I$ is associated to a percent increase in TFP, included in the interval $[0.02,0.03]$ and 1 percent increase in $R L$ is associated to a percent increase in TFP ranging between 0.04 and 0.05 . However, the level of comparative development elasticity is only statistically significant in the fixed effects model (column $3^{\prime}$ ). When equation is estimated with a common constant this coefficient does not appears to be significantly different from zero. On the other hand, with the fixed effects model it is significantly positive: ceteris paribus, 1 percent increase in the level of development implies an increase in TFP of 0.325 percent.

Considering the interaction terms (columns 4 and $4^{\prime}$ ), the sign of the coefficient of $L n R L$ turns out to be negative. The FDI effect decreases with the increase of the level of development, but it is always positive; The $R L$ effect is negative for countries with a low level of development (below 21 percent of US level). But overall, the RL have an increasing effect over TFP as the level of development increases. In our view this means that the level of development is crucial to determine the amount of profit that a country appropriates from the assets that originate the payment of royalties and license fees. On the other hand, the level of development is also important to assess the total effect of FDI on TFP at the aggregate level.

However, there is an important difference between the pooled LS with a common constant and the fixed effects model. In the estimation with a common constant the coefficient of $L n R L$ together with the coefficient of the interaction of this variable with the level of development $\left(L n R L^{*} L n y\right)$ does not appear significantly different from zero. We think that this lack of 
significance is due to the restriction imposed by the common constant that limits the possibility of accounting the heterogeneity of the different countries. The fixed effects model can accommodate such heterogeneity in the $\beta_{0 i t}=\beta_{0 i}$ term.

So, in order to come to a sound decision on whether fixed effects or pooled OLS model with a common constant is appropriate, we calculate the Joint significance $F$ test for the null and alternative following hypotheses:

$\mathrm{H}_{0}: \beta_{0 i t}=\beta_{0}$, for all $i=1, \ldots, 16$ and for all $t$ (no cross-section fixed effects);

$\mathrm{H}_{1} \beta_{0 i t} \neq \beta_{0}$, for all $i=1, \ldots, 16$ and for all $t$ (cross-section fixed effects).

As is visible from the bottom line of table 2 the joint significance $F$ test largely exceeds the critical value from the $F$ table for 15 degrees of freedom (df) of the numerator and for 220 , or slightly higher, df of the denominator, which is approximately 2.13 , at 1 per cent level of significance. So, the results imply that the null hypothesis (that there are no cross-section fixed effects) is rejected.

But, in table 2, the comparison between the columns (3) and (4) and the columns ( $\left.3^{\prime}\right)$ and (4'), respectively is illustrative of a possible problem that can affect the OLS estimates: the existence of heterocedasticity. The heterogeneity not controlled by the fixed effects can make evident that the conditional variance of TFP (which is equal to that of $u_{i}$ ) increases as comparative level of development, or $R L$, increases.

In fact, the estimates of Table 2, obtained by system OLS, have implicit the verification of the assumptions of the classic linear regression model. A critical assumption of this model is that the disturbances have the same variance. If this assumption is not satisfied we have heteroscedasticity. Although the heterocesdaticity does not destroy the unbiasedness and consistency properties of the OLS estimators make that these estimators are no longer efficient (have not the minimum variance). In such case the unbiased, consistent and efficient estimators are provided by the method of Generalized Least Squares (GLS). Thus, table 3 reports GLS estimates for the same sample and for the same regression equations previously estimated by OLS.

\begin{tabular}{|c|c|c|c|c|}
\hline & (5) & (6) & (7) & (8) \\
\hline F. Effects & a) & a) & a) & a) \\
\hline \multirow{2}{*}{ LnFDI } & $0.021^{*}$ & $0.048^{\star}$ & $0.019^{\star}$ & $0.129^{*}$ \\
\hline & (15.02) & $(4.83)$ & (15.59) & $(5.87)$ \\
\hline \multirow{2}{*}{ LnRL } & $0.047^{\star}$ & $0.062^{*}$ & $0.040^{\star}$ & $-0.097^{\star}$ \\
\hline & (12.07) & (8.07) & (17.96) & $(-4.89)$ \\
\hline \multirow{2}{*}{ LnFDI $^{*}$ LnRL } & \multirow{2}{*}{---} & $-0.0065^{*}$ & \multirow{2}{*}{---} & \multirow{2}{*}{---} \\
\hline & & $(-2.87)$ & & \\
\hline \multirow{2}{*}{ Lny } & \multirow{2}{*}{--} & \multirow{2}{*}{---} & $0.406^{*}$ & $0.345^{*}$ \\
\hline & & & (25.69) & (15.80) \\
\hline \multirow{2}{*}{ LnFDI*Lny } & \multirow{2}{*}{--- } & \multirow{2}{*}{--} & \multirow{2}{*}{---} & $-0.026^{*}$ \\
\hline & & & & $(-5.05)$ \\
\hline
\end{tabular}




\begin{tabular}{l|c|c|c|c}
\hline \multicolumn{4}{|c|}{ Table 3 - Impacts of FDI and R\&L, GLS estimates (cross section weights) continued } \\
\hline LnRL*Lny & $(5)$ & $(6)$ & $(7)$ & $(8)$ \\
\hline T & --- & -- & -- & $0.032^{*}$ \\
$\mathrm{~N}$ & & & & $(6.73)$ \\
Obs & 18 & 18 & 18 & 18 \\
\hline $\bar{R}^{2}$ & 16 & 16 & 16 & 16 \\
\hline
\end{tabular}

Source: Calculations based on OECD (2004) and World Bank (2004).

Notes: a) For saving space, the country specific effects are not reported in the table, but they are available from the author on request. t tests are shown in brackets: *significant at the 1 percent level. Standard errors and covariance matrix are White (1980) heteroscedastic corrected.

As is visible from table 3 the estimates obtained by GLS have the same signs as the coefficients estimated by OLS, but have a clear advantage in terms of statistical significance: all coefficients estimated by GLS are significant at the 1 percent level.

Based on GLS estimates, Figure 4 shows the association between level of development, FDI inflows and payment of R\&L. The $F D I$ line and the RL line are designed using the estimates of column (8) in table 3. When the level of development increases from 10 percent to 100 percent of US level, the RL effect on TFP increases from -0.02 to 0.05 and the FDI effect on TFP decreases from 0.07 to 0.009 . So, GLS estimation confirms the above said idea that the level of comparative development must be controlled if we need to access the real impact of $F D I$ and RL on TFP.

\section{Figure 4 - Effects of FDI and RL on TFP, given the level of development}

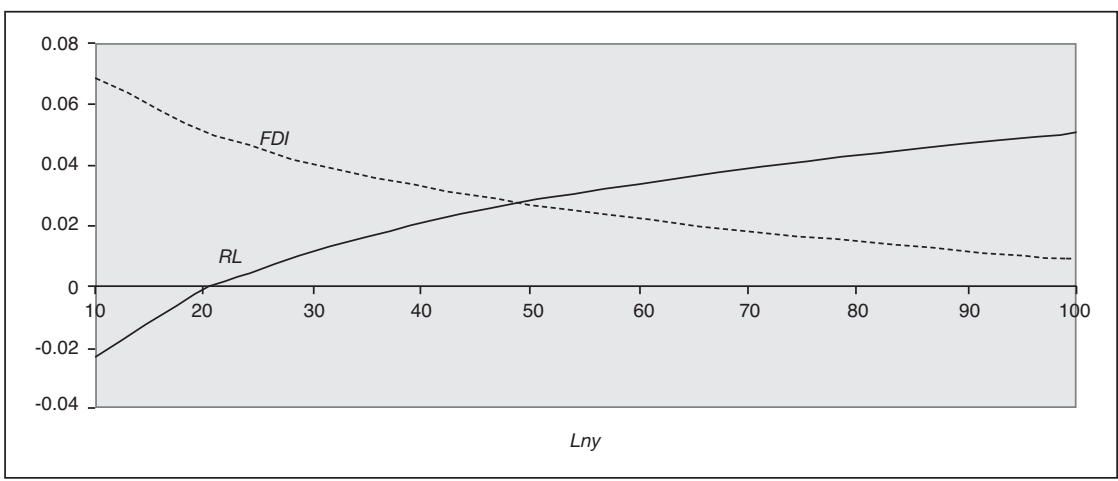

Source: The same as table 3

The GLS estimation accounts for cross-equation heteroscedasticity by minimizing the weighted sum-of-squared residuals. The equation weights are the inverses of the estimated equation variances. However, this type of GLS (with cross section weights) is not a warranty of the inexistence of autocorrelation, when we are dealing with panels of data. In these cases, autocorrelation can be not only a correlation between members of series ordered in time but also 
a correlation associated to observations not spontaneously distributed in space. So, if the possibility of autocorrelation is real, it is more prudent to use another estimation method: the one known as Seemingly Unrelated Regression (SUR) ${ }^{23}$. The SUR method, also called multivariate regression, or Zellner's method, is the feasible GLS estimator when the residuals are both cross-section heteroscedastic and contemporaneously correlated.

So, table 4 reports SUR estimates, that is, estimates that take in account heteroscedasticity, and contemporaneous correlation in the errors across equations. The results are very similar to the ones provided by GLS, both in signs and in absolute value. All the coefficients are statistically significant at 1 percent level and the level of development goes on appearing as crucial to the precise estimation of impacts of $F D I$ and RL on TFP.

\begin{tabular}{|c|c|c|c|c|}
\hline & (9) & (10) & (11) & (12) \\
\hline F. Effects & a) & a) & a) & a) \\
\hline \multirow{2}{*}{ LnFDI } & $0.022^{*}$ & $0.062^{*}$ & $0.021^{*}$ & $0.127^{*}$ \\
\hline & (23.81) & $(17.81)$ & (22.43) & $(5.41)$ \\
\hline \multirow{2}{*}{ LnRL } & $0.057^{\star}$ & $0.074^{*}$ & $0.041^{*}$ & $-0.124^{\star}$ \\
\hline & (30.42) & (32.65) & (24.74) & $(-6.62)$ \\
\hline \multirow{2}{*}{$\mathrm{LnFDI}^{*} \mathrm{LnRL}$} & \multirow{2}{*}{---} & $-0.0095^{\star}$ & \multirow{2}{*}{---} & \multirow{2}{*}{---} \\
\hline & & $(-12.24)$ & & \\
\hline \multirow{2}{*}{ Lny } & \multirow{2}{*}{---} & \multirow{2}{*}{---} & $0.333^{\star}$ & $0.242^{*}$ \\
\hline & & & (27.10) & (13.77) \\
\hline \multirow{2}{*}{ LnFDI*Lny } & \multirow{2}{*}{--} & \multirow{2}{*}{---} & \multirow{2}{*}{---} & $-0.025^{\star}$ \\
\hline & & & & $(-4.58)$ \\
\hline \multirow{2}{*}{ LnRL*Lny } & \multirow{2}{*}{--} & \multirow{2}{*}{--} & \multirow{2}{*}{---} & $0.040^{*}$ \\
\hline & & & & (8.94) \\
\hline $\mathrm{T}$ & 18 & 18 & 18 & 18 \\
\hline $\mathrm{N}$ & 16 & 16 & 16 & 16 \\
\hline Obs & 241 & 241 & 241 & 241 \\
\hline $\bar{R}^{2}$ & 0.81 & 0.84 & 0.85 & 0.86 \\
\hline
\end{tabular}

Source: Calculations based on OECD (2004) and World Bank (2004).

Notes: a) All the regressions are based on a fixed effects model. For simplicity the country specific effects are not reported in the table, but they are available from the author on request. $t$ tests are shown in brackets: *significant at the 1 percent

\section{Level of development and human capital}

We have previously argued that absorptive capacity of the host country matters. In essence, the idea is that the magnitude of FDI benefits is dependent on the ability and motivation of local firms to learn from the technology and ideas that are spilt by foreign firms. This absorptive capacity is directly related with the human capital stock, as was emphasized by the seminal paper of Nelson 
and Phelps (1966) and many others (v.g , Borensztein et al., 1998; de Mello, 1997; Ariffin and Figueiredo, 2004; Kottaridi, 2005).

Building on Nelson and Phelps (1966), several authors (for example, Cohen and Levinthal, 1989) have argued that human capital plays a dual role in promoting TFP growth: first, it enables a country to directly influence productivity by determining the capacity to innovate; second, a higher level of human capital increases the capacity of an economy to absorb foreign technology allowing a country to close the gap, between its level of productivity and that of the leading country, faster. So, a more qualified workforce can better not only render FDI more fruitful for foreign investors, but also take advantage of foreign R\&D-induced ideas and use capital goods imports (embodying advanced foreign technologies) more effectively (Pessoa, 2008).

Consequently, the positive impact of level of development on TFP and its significant interaction with $F D I$ and $R L$, reported in the previous section, can be side-products of the effect of human capital. In fact, the human capital in general and particularly the human capital that is more apt to take profit from R\&D (Research and Development) increase with the level of development, and so the latter can be acting in the regressions as a proxy of the formers. To test this hypothesis, we add to the equation (2) a variable that controls the effect of human capital on TFP.

We think that the most adequate variable for controlling the above mentioned dual role in promoting TFP is the number of Technicians in R\&D, because they are people whose main tasks require technical knowledge and experience in engineering. But, because data on Technicians in $R \& D$ are very scarce, we have chosen the number of Researchers in R\&D (RRD) per million of active people, expressed in full-time equivalent (FTE), as the feasible proxy of the human capital. Researchers in R\&D are professionals engaged in the conception or creation of new knowledge, products, processes, methods, or systems and in the management of the projects concerned, and so are an important factor in render the existent technologies more fruitful.

According to the above lines, we estimated regressions based on three methods: OLS, GLS and SUR. The results are presented in table 5 , where is also presented, one of the statistical tests introduced by Hausman in his seminal paper (1978). The time span is the same of the previous tables, but the inclusion of the number of researchers, due to the scarcity of data forced to reduce the number of observations (from 241 to 173) of the panel.

Whereas OLS estimation shows that the RRD coefficient is not significantly different from 0 , along with absence of statistical significance of $F D I$ and of the interaction between $F D I$ and the level of development, the regressions based on GLS and SUR show that all coefficients have the predict signs and are significant at a 1 percent level. However, the OLS estimates shall be unreliable. They are likely to be affected by the troubles previously detected (heteroscedasticity and autocorrelation), now aggravated by the reduction of the number of observations.

So, discarding OLS estimates, and based only on GLS and SUR methods, we can say that ceteris paribus 1 percent increase in FDI has a positive effect on TFP that can be either 0.12 percent or 0.14 percent, according to the method of estimation. On the other hand, 1 percent increase in $R L$ reduces TFP by 0.14 percent. However, this negative effect can be compensated by the interaction with the level of development, which has a positive impact on TFP. As predicted, the $R R D$ variable has a positive impact on TFP, as well as the level of comparative development.

Both GLS and SUR estimates reject the idea that the level of comparative development is only a proxy of $R D D$ and that the comparative level of development has no direct effect on TFP. On the contrary, the inclusion of $R R D$ has maintained the significance of the coefficient of the level of comparative development and, what is more, the value of TFP elasticity relatively to the level of development only has slightly varied (a small retreating in GLS estimation and slight increase in SUR estimation).

Although the absolute value of the coefficients does not present a large variation form GLS to SUR estimation, we have tried to identify, between the two, the most reliable method, using the 


\begin{tabular}{|c|c|c|c|c|}
\hline & OLS & GLS (cross section weights) & SUR & q \\
\hline & (13) & (14) & (15) & (16) \\
\hline \multirow{2}{*}{ LnFDI } & $0.1070 \dagger$ & $0.141^{*}$ & $0.118^{*}$ & $0.02302^{*}$ \\
\hline & $(1.486)$ & $(4.339)$ & $(3.754)$ & $(2.776)$ \\
\hline \multirow{2}{*}{ LnRL } & $-0.138^{\star \star *}$ & $-0.142^{*}$ & $-0.138^{*}$ & $-0.00377 \dagger$ \\
\hline & $(-1.719)$ & $(-3.794)$ & $(-4.608)$ & $(-0.169)$ \\
\hline \multirow{2}{*}{ Lny } & $0.241^{*}$ & $0.309^{*}$ & $0.255^{*}$ & $0.053751^{*}$ \\
\hline & $(4.000)$ & (10.22) & $(10.586)$ & (2.949) \\
\hline \multirow{2}{*}{ LnFDI*Lny } & $-0.0202 \dagger$ & $-0.0290^{*}$ & $-0.0230^{*}$ & $-0.00593^{*}$ \\
\hline & $(-1.197)$ & $(-3.854)$ & $(-3.165)$ & $(-3.161)$ \\
\hline \multirow{2}{*}{ LnRL*Lny } & $0.0412^{\star \star}$ & $0.0417^{*}$ & $0.0410^{\star}$ & $0.000653 \dagger$ \\
\hline & $(2.221)$ & $(4.921)$ & $(5.849)$ & $(0.137)$ \\
\hline \multirow{2}{*}{ Ln RRD } & $0.0358 \dagger$ & $0.0455^{*}$ & $0.0393^{*}$ & $0.006155 \dagger$ \\
\hline & $(1.398)$ & (3.745) & $(4.855)$ & $(0.680)$ \\
\hline$T$ & 18 & 18 & 18 & 18 \\
\hline$N$ & 16 & 16 & 16 & 16 \\
\hline Obs & 173 & 173 & 173 & 173 \\
\hline $\bar{R}^{2}$ & 0.87 & 0.99 & 0.87 & \\
\hline
\end{tabular}

Source: Calculations based on OECD (2004) and World Bank (2004, 2007).

Notes: $t$ tests are shown in brackets: * significant at the 1 percent level; ${ }^{* \star}$ significant at the 5 percent level; ${ }^{* \star *}$ significant at the 10 percent level; †not significant. In OLS and GLS estimations, standard errors and covariance matrix are White (1980) heteroscedastic corrected. All the regressions are based on a fixed effects model. For saving space the country specific effects are not reported in the table, but they are available from the author on request.

statistic that results from the procedure described in Hausman (1978). Looking at this statistic we saw mixed results. The results showed in the last column are obtained making the subtraction between the coefficients estimated according to GLS and according to SUR methods, and the tests $t$ below them are calculated from the difference between the respective variances, as in Hausman (1978). As is visible, the difference between the coefficients estimated by GLS and by SUR estimation is only significant for 3 in 6 variables. Whereas the difference in FDI, in the level of comparative development and in the interaction between these two variables is significant at a 1 percent level, the differences respecting to $R L, R R D$ and interaction between $R L$ and level of development are not statistically significant.

\section{Concluding remarks}

In this study, we have tested the effects of FDI on the aggregate TFP in a panel data of 16 OECD countries in the 1985-2002 period. Our empirical tests show that inward FDI has a positive impact on host country TFP, possibly because FDI is a channel through which technologies are transferred internationally. This conclusion corroborates both the ones of some microeconomic studies that use panel data, like the works of Liu et al. (2000), Haskel et al. (2002), Keller and Yeaple (2003) and Görg and Strobl (2003), and also the general conclusion of 
Mullen and Williams (2005), at the regional level. Accordingly our work provides support to the countries that aggressively use policy to attract investments from foreign multinational corporations. Our work also sheds some light on the consequences of the internalization decision, which is in the core of the OLI paradigm. Our data show that, when other factors remain constant, inward FDI and R\&L payments are substitutes in influencing positively TFP of the host country.

The inclusion among explanatory variables of one that controls the level of comparative development permits to illustrate the fact that the amount of positive effects of both FDI and R\&L is dependent on the level of development of the receiving country, and to confirm the suspicion of de Mello (1999) and the idea of Grossman and Helpman (1991) that the impact of FDI is lower in technological leaders than in laggard countries. Our results also demonstrate that the studies that do not control the level of development through one or several variables (education, R\&D outlays, infrastructures) - which are strongly and positively correlated with level of development - may present biased estimates.

When we consider the interaction between the level of development and $R \& L$, the negative effect of R\&L on TFP can help to explain the scarce use of patents and other 'intangible' assets as brand names and copyrights by the technological laggards and consequently the scarce technological content of production and exports of these countries. The negative impact of R\&L for low levels of development provides some rationality to the behaviour of firms of those countries that invest more heavily in machines and equipment than in paying for ideas. But, dynamically, given the complementarity between development level and $R \& L$, corroborated by positive sign of respective interaction term, the licensed use of foreign technologies can represent a means of technical renovation even in countries that are not near the technological frontier.

Finally, our study shows that the positive effect of the level of development on TFP is not exclusively due to the human capital. Even though the human capital has a direct effect on TFP, it is not a mere proxy of the country's level of development, and so studies that aim to assess the precise impact of FDI on TFP must be aware of its inclusion in the analysis. 
Aitken, B.; Harrison, A. (1999) Do Domestic Firms Benefit from Foreign Investment? Evidence from Venezuela, American Economic Review, 89, 605-618.

Aitken, B.; Hanson, G.; Harrison, A. (1997) Spillovers, Foreign Investment, and Export Behavior, Journal of International Economics, 43, 1-2, 103-32.

Alfaro, L. et al. (2004) FDI and economic growth: the role of local financial markets, Journal of International Economics 64, 89-112.

Ariffin, Norlela; Figueiredo, Paulo N. (2004) Internationalization of Innovative Capabilities: Counter-Evidence from the Electronics Industry in Malaysia and Brazil, Oxford Development Studies, 32, 4, 559-583.

Balasubramanyam, V. N. (1998) The MAI and Foreign Direct Investment in Developing Countries, Discussion Paper EC10/98, Lancaster University.

Balasubramanyam, V. N.; Salisu, M.; Dapsoford, D. (1996) Foreign Direct Investment and Growth in EP and IS Countries, Economic Journal 106, 92-105.

Blomström, M.; Kokko, A. (1998) Multinational Corporations and Spillovers, Journal of Economic Surveys, 12, 2, 1-31.

Blomström, M.; Kokko, A. (2003) The Economics Of Foreign Direct Investment Incentives, Working Paper n. 9489, National Bureau Of Economic Research.

Blomström, M.; Persson, H. (1983) Foreign Investment and Spillover Efficiency in an Underdeveloped Economy: Evidence from the Mexican Manufacturing Industry, World Development, 11(6): 493-501.

Blomström, M.; Lipsey, R.E.; Zejan, M. (1994) What explains the Growth of Developing Countries? In: William J. Baumol, Richard R. Nelson and Edward N. Wolff (eds.), Convergence of Productivity: Cross-National Studies and Historical Evidence, New York, Oxford University Press, 243-259.

Borensztein, E.; De Gregorio, J.; Lee, J.W. (1998) How does foreign investment affect growth?, Journal of International Economics, 45, 115-35.

Boyd, J. H.; Smith, B.D. (1992) Intermediation and the Equilibrium Allocation of Investment Capital: Implications for Economic Development, Journal of Monetary Economics, 30, 409-432.

Brainard, S. L.; (1997) An Empirical Assessment of the Proximity-Concentration Trade-Off between Multinational Sales and Trade, American Economic Review, 87, 4, 520-44.

Brecher, R.; Diaz-Alejandro, C. (1977) Tariffs, Foreign Capital and Immiserizing Growth, Journal of International Economics, 7, 317-322.

Brecher, R. (1983) Second-Best Policy for International Trade and Investment, Journal of International Economics, 14, 313-320.

Campos, N.F.; Kinoshita, Y. (2002) FDI as technology transferred: some panel evidence from transition economies, The Manchester School, 70, 3, 398-419.

Cantwell, J. (1989) Technological Innovation and Multinational Corporations, Oxford: Basil Blackwell.

Carkovic, M.; Levine, R. (2002) Does Foreign Direct Investment Accelerate Economic Growth?, University of Minnesota, Working Paper.

Carr, D.L.; Markusen, J.R.; Maskus, K.E. (2001) Estimating the Knowledge-Capital Model of the Multinational Enterprise, American Economic Review, 91, 3, 693-708. 
Castellani, D.; Zanfei, A. (2006) Multinational Firms, Innovation and Productivity, Cheltenham, Edward Elgar.

Caves, R. E. (1996) Multinational Enterprise and Economic Analysis, 2nd edition, Chapter 1, Cambridge, Cambridge University Press.

Caves, R. E. (1974) Multinational Firms, Competition and Productivity in Host-Country Markets, Economica 41, 162, 176-93.

Chowdhury, A.; Mavrotas, G. (2006) FDI and Growth: What Causes What?, World Economy, 29, 1, 9-19.

Chuang, Y.-C.; Hsu, P.-F. (2004) FDI, trade, and spillover efficiency: evidence from China's manufacturing sector, Applied Economics, 36, 1103-1115.

Coe, D.; Helpman, E. (1995) International R\&D Spillovers, European Economic Review, 39, 5, 214-42.

Coughlin, C. C.; Segev, E. (2000) Location Determinants of New Foreign-Owned Manufacturing Plants, Journal of Regional Science, 40, 2, 323-51.

Coughlin, C. C.; Terza, J. V.; Arromdee, V. (1991) State Characteristics and the Location of Foreign Direct Investment within the United States. Review of Economics and Statistics, 73, 4, 675-83.

De Gregorio, J. (1992) Economic growth in Latin America, Journal of Development Economics, 39, 58-84.

De Mello, L. R. (1997) Foreign Direct Investment in Developing Countries and Growth: A Selective Survey, Journal of Development Studies, 34, I, I-34.

De Mello, L. R. (1999) Foreign Direct Investment-led Growth: Evidence from Time Series and Panel Data, Oxford Economic Papers, 51, 133-151.

Driffield, N. (2001) The Impact on Domestic Productivity of Inward Investment into the UK, Manchester School, 69, 1, 103-119.

Driffield, N.; Munday, M.; Roberts, A. (2002) Foreign Direct Investment, Transactions Linkages, and the Performance of the Domestic Sector, International Journal of the Economics of Business, 9, 3, 335-51.

Dunning, J. H. (1981) International Production and the Multinational Enterprise, London, George Allen, and Unwin.

Dunning, John H. (1988) The Eclectic Paradigm of International Production: A Restatement and Some Possible Extensions, Journal of International Business Studies, 19, 1, 1-31.

Evenson, R. E.; Westphal, L. (1995) Technological Change and Technology Strategy, in: Jere Behrman and T. N. Srinivasan (eds.), Handbook of Development Economics, vol. 3, Amsterdam, North-Holland.

Findlay, R. (1978) Relative Backwardness, Direct Foreign Investment, and the Transfer of Technology: A Simple Dynamic Model, Quarterly Journal of Economics, 92, 1, 1-16.

Fosfuri, A.; Motta, M.; Ronde, T. (2001) Foreign Direct Investment and Spillovers through Workers' Mobility, Journal of International Economics, 53, 1, 205-22.

Germidis, D. (1977) Transfer of Technology by Multinational Corporations, OECD, Paris.

Gershenberg, I. (1987) The Training and Spread of Managerial Know-how, a Comparative Analysis of Multinational and Other Firms in Kenya, World Development, 15, 7, 931-39.

Glass, A.; Saggi, K. (1998) International Technology Transfer and the Technology Gap. Journal of Development Economics, 55, 2, 369-98. 
Görg, H.; Greenaway, D. (2004) Much Ado about Nothing: Do Domestic Firms Really Benefit from Foreign Direct Investment, The World Bank Researcher Observer, 19, 2, 171-197.

Görg, H.; Strobl, E. (2003) Multinational Companies, Technology Spillovers and Plant Survival, Scandinavian Journal of Economics, 105, 4, 581-95.

Graham, E.; Krugman, P. (1991) Foreign Direct Investment in the United States, Institute for International Economics, Washington D.C.

Griffith, R. (1999) Using the ARD Establishment Level Data to Look at Foreign Ownership and Productivity in the UK. Economic Journal, 109, F416-F442.

Grossman, G.; Helpman, E. (1991) Innovation and Growth in the Global Economy. Cambridge, MA: MIT Press.

Haddad, M.; Harrison, A. (1993) Are there positive spillovers from direct foreign investment? Evidence from panel data for Morocco, Journal of Development Economics, 42, 1, 51-74.

Hanson, G. H. (2001). Should Countries Promote Foreign Direct Investment?, G-24 Discussion Paper Series, UNCTAD.

Harrison, A. (1996) Determinants and Consequences of Foreign Investment in Three Developing Countries, in Mark, Roberts; Tybout, James (eds.), Industrial Evolution in Developing Countries: Micro Patterns of Turnover, Productivity, and Market Structure, Oxford: Oxford University Press.

Haskel, J. E.; Pereira, S. C.; Slaughter, M. J. (2002). Does Inward Foreign Direct Investment Boost the Productivity of Domestic Firms?, NBER Working Paper n. 8724, National Bureau Of Economic Research.

Katz, J. M. (1969) Production Functions, Foreign Investment and Growth, Amsterdam, North Holland.

Keller, W. (1998) Are international R\&D spillovers trade related? Analyzing spillovers among randomly matched trade partners, European Economic Review, 42, 1469-1481.

Keller, W.; Yeaple, S. R. (2003) Multinational Enterprises, International Trade, And Productivity Growth: Firm Level Evidence From The United States, NBER Working Paper n. 9504, National Bureau Of Economic Research.

Keller, W. (1996) Absorptive Capacity: Understanding the Creation and Acquisition of Technology in Development, Journal of Development Economics, 49, 199-227.

Kholdy, S. (1995) Causality between Foreign Investment and Spillover Efficiency, Applied Economics, 27, 745-49.

Kokko, A. (1996) Productivity Spillovers from Competition between Local Firms and Foreign Affiliates, Journal of International Development, 8, 517-530.

Konings, J. (2001) The Effects of Foreign Direct Investment on Domestic Firms: Evidence from Firm Level Panel Data in Emerging Economies, Economics of Transition, 9, 3, 619-33.

Kottaridi, C. (2005) The 'core-periphery' pattern of FDI-led growth and production structure in the EU, Applied Economics, 37, 99-113.

Kugler, M. (2000) The Diffusion of Externalities from Foreign Direct Investment: Theory Ahead of Measurement, Discussion Papers in Economics and Econometrics, University of Southampton, U.K.

Lall, S. (1992). Technological Capabilities and Industrialization, World Development, 20, 2, 165-86.

Larrain, F. B.; Lopez-Calva, L. F.; Rodriguez-Clare, A. (2000) Intel: A Case Study of Foreign Direct Investment in Central America, Center for International Development Working Paper 58, Harvard University. 
Lichtenberg, F.; van Pottelsberghe de la Potterie, B. (1996) International R\&D spillovers: A re-examination, NBER working paper n. 5668, National Bureau Of Economic Research.

Lim, L.; Fong, P. E. (1982) Vertical Linkages and Multinational Enterprises in Developing Countries, World Development, 10, 7, 585-95.

Lipsey, R.E. (2002) Home and Host Country Effects of FDI, NBER Working Paper n. 9293, National Bureau Of Economic Research.

Liu, X. et al. (2000) Productivity Spillovers from Foreign Direct Investment: Evidence from UK Industry Level Panel Data, Journal of International Business Studies, 31, 3, 407-425.

Mansfield, E.; Romeo, A. (1980) Technology Transfer to Overseas Subsidiaries by US-based Firms, Quarterly Journal of Economics, 95, 4, 737-50.

Markusen, James (1995) The Boundaries of Multinational Enterprises and the Theory of International Trade, Journal of Economic Perspectives, 9, 1, 169-89.

Markusen, James; Maskus, K. (1999) Discrimination among Alternative Theories of FDI, NBER Working Paper 7164, National Bureau Of Economic Research.

Moran, T. (2001) Parental Supervision: the new paradigm for foreign direct investment and development, Washington, DC, Institute for International Economics.

Mudambi, R.; Navarra, R. (2002). Institutions and international business: A theoretical overview. International Business Review, 11, 6, 635-646.

Mullen, J. K.; Williams, M. (2005) Foreign Direct Investment and Regional Economic Performance, Kyklos, 58, 2, 265-282.

Narula, R. (2003) Globalization \& Technology, Cambridge (UK), Polity Press.

Narula, R.; Dunning, John H. (2000). Industrial development, globalization and multinational enterprises: New realities for developing countries. Oxford Development Studies, 28, 2, 141-167.

OECD (2002) Foreign Direct Investment for Development: Maximising Benefits, Minimising Costs, OECD, Paris.

OECD (2004) Multifactor productivity based on harmonized prices for ICT capital goods-data: indices and percentage changes, OECD Productivity database, 17 December.

Pessoa, A. (2008) MNCs, FDI and Host Country Productivity: A Theoretical and Empirical Appraisal, The ICFAl University Journal of Managerial Economics, 6, 4, 25-66.

Rhee Y. W.; Belot, T. (1990) Export Catalysts in Developing Countries: A Review of Eleven Success Stories, Washington, DC, World Bank, Discussion Paper n. 72.

Rivera-Batiz, F.; Rivera-Batiz, L. (1990) The effects of direct foreign investment in the presence of increasing returns due to specialization, Journal of Economic Development, 34, 2, 287-307.

Rodriguez-Clare, A. (1996) Multinationals, Linkages, and Economic Development, American Economic Review, 86, 4, 852-73.

Romer, P. (1993) Idea gaps and object gaps in economic development, Journal of Monetary Economics, 32, 3, 543-573.

Sjöholm, F. (1999) Productivity Growth in Indonesia: The Role of Regional Characteristics and Direct Foreign Investment, Economic Development and Cultural Change, 47, 3, 559-584.

Smarzynska, B. K. (2004) Does Foreign Direct Investment Increase the Productivity of Domestic Firms? In Search of Spillovers through Backward Linkages, American Economic Review, 94, 3 , 605-627.

Solow, R. M. (2001) What have we learned from a decade of empirical research on growth? Applying growth theory across countries, The World Bank Economic Review, 15, 2, 283-288. 
Teece, D. J. (1977) Technology Transfer by Multinational Firms: The Resource Cost of Transferring Technological Know-How, Economic Journal, 87, 242-261.

Wheeler, D.; Mody, A. (1992) International Investment Location Decisions: The Case of U.S. Firms, Journal of International Economics, 33, I-2, 57-76.

White, H. (1980) A heteroscedasticity-consistent covariance matrix estimator and a direct test for heteroscedasticity, Econometrica, 48, 817-838.

World Bank (2004, 2007) World Development Indicators (WDI-CDRom).

Xu, B. (2000) Multinational Enterprises, Technology Diffusion, and Host Country Productivity Growth, Journal of Development Economics, 62, 477-493.

Zellner, A. (1962) An Efficient Method of Estimating Seemingly Unrelated Regressions and Tests of Aggregation Bias, Journal of the American Statistical Association, 57, 348-368. 